\title{
IНСТРУМЕНТАРІЙ З ВИВЧЕННЯ ДУМКИ ФАХІВЦІВ ДЕРМАТОВЕНЕРОЛОГІЧНОГО ПРОФІЛЮ З ПИТАНЬ ПРОФЕСІЙНОЇ ДІЯЛЬНОСТІ ЗА УМОВ РЕФОРМУВАННЯ ОХОРОНИ ЗДОРОВ'Я
}

\author{
Національний медичний університет імені О. О. Богомольця, м. Київ, Україна
}

\begin{abstract}
Мета: виявити перспективні напрями удосконалення медичної допомоги населенню та обґрунтувати інструментарій з вивчення думки фахівців дерматовенерологічного профрілю 3 питань професійної діяльності за умов реформування охорони здоров'я.

Матеріали і методи. Використано бібліографічний, медико-статистичний, інформаційно-аналітичний методи. Основою дослідження стали дані наукової літератури, стратегії та програми ВООЗ, ЄРБ ВООЗ, що регламентують організацію надання послуг охорони здоров'я та забезпечення їх якості; дані Центру медичної статистики МОЗ України.

Результати. Медико-соціальним дослідженням встановлено сучасні проблеми та стратегічні напрями удосконалення медичного обслуговування населення щодо загального охоплення послугами охорони здоров'я 3 огляду на виклики та загрози, сучасний демографрічний, епідеміологічний контекст тощо.

Виявлено тенденції захворюваності та поширеності хвороб шкіри та підшкірної клітковини серед населення України, зміни в забезпеченості населення фрахівцями дерматовенерологічного профрілю за період 2000-2017 рр.

Обґрунтовано інструментарій 3 вивчення думки спеціалістів дерматовенерологічного профрілю 3 питань професійної діяльності за умов реформування охорони здоров'я, з включенням до нього запитань демографрічного, економічного, медичного, виробничого, ресурсного, освітнього, інорормаційного характеру, а також запитань щодо впливу пандемії COVID-19 на виробничі умови та результати роботи щодо наявних проблем та потреб.

Висновки. Проведення соціологічного дослідження серед фрахівців дерматовенерологічного профрілю за допомогою запропонованого інструментарію сприятиме з'ясуванню проблемних питань виробничої діяльності фрахівців за умов реформування, бачення перспектив розвитку, дозволить обґрунтувати напрями та заходи з удосконалення організації надання дерматовенерологічної допомоги.
\end{abstract}

КЛЮчОВІ СЛОВА: організація медичної допомоги; дерматовенерологічний профіль; кадри; інструментарій; соціологічне дослідження; професійний розвиток; умови праці; ресурсне забезпечення; COVID-19; ресрормування.

За умов реформування національної системи охорони здоров'я перед різними її службами постає безліч питань нормативно-правового, організаційно-управлінського, фрінансово-економічного, науково-освітнього характеру тощо. Вони пов'язані з тенденціями в стані здоров'я населення, змінами в потребі в різних видах та профрілях медичного обслуговування, запровадженням нових організаційних фрорм у наданні послуг, фрінансуванні, управлінні, генеруванні ресурсів, зі зміною фрілософії та парадигми охорони здоров'я в цілому. За таких умов необхідним є науковий супровід організаційних змін у системі медичної допомоги та громадського здоров'я з урахуванням наявного контексту та стратегічного спрямування.

Досягнення цілей у сорері сталого розвитку на період до 2030 р. передбачає забезпечення належного рівня здоров'я і благополуччя населення. Серед передумов реалізації цієї стратегічної цілі важливе місце посідає система надання послуг охорони здоров'я, яка має бути реформова-

(c) Т. С. Грузєва, В. В. Короленко, 2020 на відповідно до викликів та загроз XXI століття 3 метою підвищення рівня їх орієнтованості на результати і застосування концептуального підходу для обґрунтування необхідних взаємодій [16].

Потребують обґрунтування ключові рішення, спрямовані на узгодження процесів реформування охорони здоров'я з урахуванням сучасних викликів та загроз як для здоров'я населення, так і для системи охорони здоров'я [3, 15].

Сучасні демографрічні тренди свідчать про значні темпи старіння в багатьох регіонах світу та невпинне збільшення частки осіб старших вікових груп у загальній віковій структурі населення. Незважаючи на зусилля світової спільноти щодо забезпечення здорового старіння, зростання поширеності неінфекційних захворювань зумовлює збільшення питомої ваги людей старших вікових груп, які потребують різнопрофрільної медичної допомоги, часто, довготривалого лікування та догляду $[2,9,17]$.

3 іншого боку, прогрес у розвитку медичних технологій дозволяє суттєво розширити їх вико- 
ристання при різних фрормах патології, збільшити обсяги наданих послуг, охоплення ними населення, підвищити ефективність медичного обслуговування, його доступність і якість. Це створює умови для пришвидшення досягнення загального охоплення населення послугами охорони здоров'я як стратегічної цілі системи охорони здоров'я [13].

У даному контексті важливим є забезпечення охоплення медичним обслуговуванням усіх вікових груп населення, починаючи з наймолодшого віку, поліпшення показників здоров'я і його детермінант протягом усього життєвого шляху людини, переорієнтація моделей надання допомоги на оптимальний набір популяційних втручань та індивідуальних послуг і впровадження тих, які орієнтовані на потреби людей з механізмами зворотного зв'язку [7].

Важливим викликом, з якою зіткнулася система охорони здоров'я в усьому світі, є зростаючий попит на послуги охорони здоров'я за умов поширення COVID-19. Система охорони здоров'я виявилася перевантаженою, спостерігають тенденцію до зниження доступності необхідної медичної допомоги, зростає смертність через спалахи хвороб та через захворювання, що потребують профрілактики і лікування. Для вчасного звернення людей за медичною допомогою і дотримання медичних рекомендацій необхідною $€$ підтримка довіри населення до системи охорони здоров'я, яка здатна забезпечувати задоволення основних потреб і контролювати ризик поширення інфекцій в закладах охорони здоров'я [6, 12].

Окрім численних питань медичного обслуговування населення нормативно-правового, організаційно-управлінського, фрінансово-економічного, науково-освітнього характеру, існують проблеми кадрового забезпечення медичної допомоги, підготовки та безперервного професійного розвитку кадрів, реалізації мультидисциплінарного підходу в процесі надання медичної допомоги та дотримання іiї принципів і стандартів, забезпечення доступності та якості [5, 14].

ВООЗ наголошує на необхідності удосконалення політики щодо забезпечення населення медичною допомогою належної якості та створення умов для ефективної роботи кадрових ресурсів, які надають медичні послуги.

Питання удосконалення надання медичної допомоги є надзвичайно актуальними для України 3 огляду на епідеміологічний контекст, значну потребу населення в медичних послугах, наявні проблеми фрінансування та реорганізаційні зміни в національній системі охорони здоров'я.

Зважаючи на суттєвий внесок дерматовенерологічної патології у фрормування загального тягаря хвороб, значну її частку в структурі захворюваності, негативний вплив на якість життя населення, удосконалення медичного обслугову- вання пацієнтів даного профілю є важливим завданням охорони здоров'я.

Визначення напрямів та шляхів удосконалення дерматовенерологічної служби потребує, серед іншого, вивчення думки надавачів послуг - фрахівців вказаного профілю щодо наявних проблем та шляхів їх вирішення. Це зумовлює необхідність обґрунтування та розробки відповідного інструментарію.

Мета дослідження: виявити перспективні напрями удосконалення медичної допомоги населенню та обґрунтувати інструментарій 3 вивчення думки фрахівців дерматовенерологічного профрілю з питань професійної діяльності за умов реформування охорони здоров'я.

Матеріали і методи. Методологія дослідження передбачала використання бібліографрічного, медико-статистичного та інфрормаційно-аналітичного методів.

До завдань дослідження входило виявлення пріоритетів в організації медичного обслуговування населення, у формуванні кадрового потенціалу медичних служб, з'ясуванні найбільш важливих питань в організації надання медичної допомоги за даними міжнародних документів, наукових публікацій і розробка інструментарію соціологічного дослідження щодо сучасних проблем та наявних потреб фахівців дерматовенерологічного профрілю.

Основою дослідження стали дані наукової літератури, стратегії та програми ВООЗ, ЄРБ ВОО3, що регламентують організацію надання послуг охорони здоров'я та забезпечення їх якості; дані Центру медичної статистики МОЗ України.

Проаналізовано захворюваність населення України на хвороби шкіри та підшкірної клітковини впродовж 2000-2017 рр. та поширеність цієї патології серед населення, її питому вагу в загальній структурі захворюваності за даними Центру медичної статистики МОЗ України. Досліджено тенденцію кадрового забезпечення фрахівцями дерматовенерологічної служби впродовж сімнадцятилітнього періоду. Узагальнення результатів виконаних завдань дослідження дозволило обґрунтувати та розробити анкету з вивчення думки фрахівців дерматовенерологічного профрілю щодо проблем професійної діяльності та шляхів їх вирішення.

Результати дослідження та їх обговорення. Обґрунтування інструментарію соціологічного дослідження щодо сучасних проблем та наявних потреб фрахівців дерматовенерологічного профілю здійснювали з урахуванням сучасних реалій надання медичної допомоги та перспективного бачення її розвитку на глобальному, регіональному та національному рівнях.

Вивчення концептуальних і програмних документів ВООЗ та Європейського регіонального бюро ВООЗ виявило загальні проблеми ефек- 
тивності фрункціонування медичних служб, фрормування їх кадрового потенціалу та напрями вирішення цих проблем.

У виданні «Підвищення якості медичного обслуговування в Європейському регіоні: характеристики, ефективність і реалізація різних стратегій», підготовленому Європейською обсерваторією з систем і політики охорони здоров'я, розкрито концептуальну основу для розуміння і застосування стратегій забезпечення якості медичного обслуговування [1]. Охарактеризовано численні ініціативи щодо підвищення якості медичної допомоги. Ці ініціативи мають різні форми, наприклад, розробка стандартів для працівників, технологій і медичних закладів, аудит та зворотний зв'язок, розвиток культури безпеки пацієнтів, підзвітність перед громадськістю, схеми оплати за високу якість тощо. Для менеджерів медичних служб, які ведуть пошук найкращих ініціатив із вкладення коштів, вирішальне значення має розуміння потенціалу запропонованих стратегій забезпечення якості. Критична оцінка різних стратегій забезпечення якості медичної допомоги та наведені рекомендації для їх здійснення є вагомим підґрунтям для обґрунтування шляхів удосконалення організації надання медичної допомоги.

Важливе значення для розуміння перспектив оптимізації медичного забезпечення населення має Європейська рамкова основа дій з організації інтегрованого надання послуг охорони здоров'я. У даному документі визначено чотири пріоритетні сорери, а саме: групи населення та окремі особи; процеси надання послуг; сприяння роботі системи охорони здоров'я та управління змінами [4]. Зокрема, у сорері груп населення і окремих осіб необхідним $€$ визначення їх потреб у медичних послугах; вплив на детермінанти; розширення прав і можливостей різних груп населення; залучення пацієнтів до процесу удосконалення послуг охорони здоров'я. Досягти цього можливо шляхом визначення та реалізації ключових стратегій і дослідженням різних ресурсів, включаючи інструменти, керівництва, приклади з практики та баз даних, які можна використовувати в оптимізаційних цілях. У сорері надання послуг першочергової уваги потребують розробка послуг медичної допомоги, організація постачальників і умов надання послуг, керівництво процесом надання послуг та підвищення еорективності. Сприяння роботі системи включає реорганізацію структури підзвітності, узгодження стимулів, забезпечення компетентними кадрами, відповідальне використання ліків, введення інноваційних технологій та розвиток електронної охорони здоров'я. При цьому управління змінами має передбачати застосування стратегій, орієнтованих на потреби людей, здійснення перетворень, сприяння стійким змінам.
Нові умови, в яких фрункціонують сьогодні медичні служби внаслідок пандемії COVID-19, потребують зважених підходів до планування розвитку системи медичної допомоги. У Рекомендаціях стосовно політики для Європейського регіону ВОО3 «Вдосконалення і адаптація заходів у сорері громадського здоров'я при переході між етапами боротьби з COVID-19» наголошується на необхідності можливостей подвійної системи управління охороною здоров'я, яка дозволятиме одночасно відновити повноцінну роботу медичних служб і продовжувати боротьбу з COVID-19 [4]. Важливу роль при цьому відводять адаптації первинної медичної допомоги для підвищення есрективності дій у відповідь, забезпечення доступності медичної допомоги, її своєчасності та наступності в наданні її ланками загальної практики та спеціалістами [10].

Організація медичної допомоги за умов пандемії COVID-19 повинна враховувати конкретні умови її надання, корегувати механізми управління і координації для сприяння прийняттю своєчасних заходів, встановлювати пріоритетність основних медичних послуг, адаптувати їх до постійних змін умов і потреб, оптимізувати умови і платформи для надання послуг, забезпечувати безпечний та ефективний потік пацієнтів на всіх рівнях, оперативно оптимізувати потенціал кадрових ресурсів, забезпечити безперервну доступність основних лікарських препаратів, обладнання, засобів і матеріалів, фрінансувати надання послуг та усувати фрінансові перешкоди для доступу до їх отримання, посилювати стратегії комунікації та контроль за основними медичними послугами, використовувати цисррові платформи на підтримку їх надання [11].

Особливої уваги в процесах реформування медичного обслуговування заслуговують кадрові ресурси. Аналіз Глобальної стратегії для розвитку кадрових ресурсів охорони здоров'я: трудові ресурси 2030 р. дозволив визначити пріоритетні цілі в даному контексті, які полягають у підвищенні ефрективності, якості та результативності діяльності медичних кадрів; збільшенні інвестицій в кадрові ресурси, їх узгодженості з наявними потребами населення; створенні інорраструктури для управління політикою, лідерства та керівництва діяльністю; фрормуванні даних про медичні кадри для моніторингу та забезпечення підзвітності [5]. 3 огляду на вказані стратегічні цілі, окреслено пріоритетні завдання з удосконалення кадрової складової медичної допомоги.

У методичному посібнику із забезпечення стійких трудових ресурсів охорони здоров'я в Європейському регіоні ВООЗ вказано, що медичним працівникам належить найважливіша роль в системі охорони здоров'я щодо забезпечення стійкості, надання високоякісних послуг, здатності 
долати негативні зовнішні впливи [8]. Досягнення стратегічних цілей системи охорони здоров'я в контексті надання високоякісної допомоги населенню передбачає належну систему навчання кадрів та забезпечення безперервного профресійного розвитку, якісне виконання професійних обов'язків медичним персоналом, планування послуг і ресурсів та узгодження інвестицій, зміцнення ресурсного потенціалу з постійним аналізом та моніторингом.

Підняті у розглянутих документах питання $€$ важливими для удосконалення медичної допомоги будь-якого профрілю, їх необхідно враховувати при обґрунтуванні шляхів удосконалення різних медичних служб, у тому числі дерматовенерологічної. Це зумовлюється масштабністю захворюваності на хвороби шкіри та підшкірної клітковини, її внеску в фрормування загального тягаря нездоров'я, у зниження якості життя населення.

Аналіз даних Центру медичної статистики МO3 України свідчить, що незважаючи на деяке зменшення поширеності хвороб шкіри та підшкірної клітковини серед населення країни впродовж 2000-2017 рр. (з 4763,9 до 4529,1 на 100 тис., або на 4,9\%) та захворюваності на вказану патологію (3 4036,1 до 3688,4 на 100 тис., або на 8,6 \%), рівень її залишається високим. Питома вага дерматологічної патології в структурі захворюваності населення, як і раніше, становить 5,9\%, що свідчить про вагомий внесок у формування тягаря нездоров'я.

У даному контексті важливе значення має вивчення думки спеціалістів дерматовенерологічного профілю з численних проблем їх професійної діяльності та фрункціонування дерматовенерологічної служби. 3 огляду на вказане, відповідно до завдань розроблено інструментарій для проведення соціологічного дослідження серед лікарів дерматовенерологічного профілю щодо проблем їх діяльності, існуючих потреб, бачення шляхів розвитку відповідної служби.

Вивчення думки фрахівців є надзвичайно важливим 3 огляду на скорочення їх чисельності в Україні впродовж 2000-2019 рр. на 27,7 \%, забезпеченості ними населення - 17,8 \%, збільшення навантаження тощо. За даними Центру медичної статистики МО3 України, укомплектованість штатних посад дерматовенерологів становила у 2019 р. 90,0 \%, що позначалося на обсягах діяльності.

Розроблений інструментарій $є$ анонімною анкетою $з$ вивчення питань професійної діяльності фрахівців дерматовенерологічного профрілю за умов ресрормування охорони здоров'я. Анкета включає 64 питання, що характеризують різнобічні аспекти діяльності лікарів дерматовенерологічного профрілю.
Метою опитування надавачів медичних послуг дерматовенерологічного профрілю $€$ вивчення умов праці, можливостей їх професійного розвитку, виявлення наявних проблем у реалізації покладених на них функцій та встановлення потреб.

Інструментарій містить декілька блоків запитань. Вони дозволяють отримати професійні та демографрічні характеристики респондентів, оцінити умови здійснення повсякденної роботи 3 надання медичних послуг, думок за доступністю та якістю офтальмологічної допомоги, наявних проблем та підходів до їх вирішення.

Демографічний блок включає традиційні для такого виду анкет запитання щодо віку, статі, місця проживання. При цьому деталізація вікових груп спеціалістів дерматовенерологічного профрілю дозволяє визначити у віковій структурі відносно молоді групи фрахівців, групи фрахівців працездатного віку з різним стажем та пенсійного віку, що важливо для прогнозування вибуття кадрів 3 профресії.

Для з'ясування профресійного бачення проблем надання дерматовенерологічної допомоги інструментарій включає запитання відносно стажу роботи надавачів послуг та їх кваліфікаційної категорії, місця роботи, займаної посади, наукового ступеня (за наявності) як істотного чинника формування світогляду та критичного мислення.

Економічний блок запитань дозволяє отримати характеристики матеріального становища спеціалістів дерматовенерологічного профрілю 3 широкою диференціацією відповідей.

Медична частина анкети стосується виявлення рівня здоров'я респондентів з оцінками від дуже доброго до дуже поганого.

3'ясування питань професійної діяльності включає самооцінку дерматовенерологами доступності та якості медичних послуг, які вони надали пацієнтам закладів охорони здоров'я, та виявлення чинників, які сприяють цьому чи, навпаки, ускладнюють досягнення високої якості роботи і належної доступності послуг. Анкетою запропоновано значний перелік різних чинників, які можуть позначатися на результатах профресійної діяльності, та можливість вписати свої відповіді.

Освітній блок анкети спрямовано на виявлення можливостей безперервного професійного розвитку кадрів дерматовенерологічного профілю з оцінкою достатності отриманих теоретичних знань, практичних навичок і компетентностей в контексті різних фрорм навчання та підвищення кваліфрікації 3 визначенням найбільш перспективних, з'ясуванням проблем у вдосконаленні інформаційно-освітніх складових.

Блок ресурсного забезпечення виробничої діяльності включає оцінку надавачами медичних послуг дерматовенерологічного просрілю 
наявного матеріально-технічного забезпечення та його відповідності нормативному, виявлення потреб у вдосконаленні технологічної оснащеності робочого місця, закладу, освоєнні нових методів лікування та діагностики дерматовенерологічної патології.

3 огляду на пріоритетний розвиток електронної охорони здоров'я інструментарій передбачає виявлення комп'ютерної оснащеності робочих місць фрахівців дерматовенерологічного профілю і закладу охорони здоров'я в цілому, безперебійної роботи комп'ютерної техніки.

Інорормаційний блок анкети включає з'ясування наявності у фахівців виходу до мережі «Інтернет», доступу до комп'ютерних баз даних доказової медицини, зокрема Кохрейнівської бібліотеки, Medline тощо, а також використання цих можливостей у своїй профресійній діяльності, з ранжуванням різних медико-інформаційних джерел за важливістю.

Вивчення думок спеціалістів дерматовенерологічного профрілю щодо проблем їх професійної діяльності стосується також з'ясування існуючого навантаження, його особливостей за умов реформування надання медичної допомоги, наявності та причин сумісництва, різних додаткових навантажень, системи стимулів і винагород. Анкета включає запитання відносно задоволеності лікарів-дерматовенерологів оплатою праці, об'єктивної оцінки її розміру відносно обсягів виконаної роботи, її складності та напруженості щодо ставлення фрахівців до професійної діяльності в планах на майбутнє.

Окремий блок анкети стосується професійної діяльності дерматовенерологів за умов пандемії COVID-19. Запитання блоку спрямовано на з'ясування впливу пандемії на умови праці, труднощів, які виникли в професійній діяльності, змін медичної активності пацієнтів, першочергових заходів для удосконалення медичного обслуговування пацієнтів дерматовенерологічного профрілю за умов пандемії тощо.

Перспективний погляд спеціалістів дерматовенерологічного профрілю на майбутнє професійної діяльності визначається низкою запитань щодо поінформованості про реформування медичної сорери, організаційні засади надання дерматовенерологічної допомоги, можливості розвитку структурного підрозділу, закладу охорони здоров'я в цілому в загальному контексті реформ.

\section{Висновки}

Аналіз міжнародних документів зі забезпечення населення послугами охорони здоров'я та розвитку медичної допомоги дозволив виявити пріоритетні сорери, які стосуються груп населення та окремих осіб; процесів надання медичних послуг; сприяння роботі системи охорони здоров'я в цілому та управління змінами. Оптимізація надання медичних послуг полягає в удосконаленні медичної допомоги, поліпшенні організації постачальників і умов надання послуг, кращому керівництві процесом надання послуг та підвищенні його ефективності.

Обґрунтування шляхів удосконалення різних медичних служб потребує врахування стратегічних напрямів розвитку медичної допомоги, національного контексту, епідеміологічної ситуації та реальних можливостей системи охорони здоров'я.

Необхідність удосконалення організації діяльності дерматовенерологічної служби зумовлена високими рівнями захворюваності населення на дерматовенерологічну патологію, суттєвою її часткою у загальній структурі захворюваності (5,9 \%), значним внеском у фрормування тягаря нездоров'я та зниження якості життя населення, суттєвим скороченням кадрового забезпечення впродовж 2000-2017 рр. (на 17,8 \%).

Обґрунтування напрямів та заходів з удосконалення організації діяльності дерматовенерологічної служби потребує вивчення та врахування думки фрахівців даного профрілю - як надавачів медичних послуг. 3 цією метою розроблено відповідний інструментарій у вигляді анкети, яка включає 67 запитань, представлених у демографрічному, економічному, медичному, виробничому, ресурсному, освітньому, інфрормаційному блоках тощо. Низка запитань стосується впливу пандемії COVID-19 на умови профресійної діяльності дерматовенерологів, наявних проблем та потреб за сучасних умов реформування медичної сорери.

Проведення соціологічного дослідження серед фахівців дерматовенерологічного профрілю за допомогою запропонованого інструментарію сприятиме з'ясуванню проблемних питань виробничої діяльності фахівців за умов реформування, бачення перспектив розвитку, а його результати будуть використані для обґрунтування удосконалення організації надання дерматовенерологічної допомоги.

Перспективи подальших досліджень передбачають використання запропонованого інструментарію для з'ясування думки спеціалістів дерматовенерологічного профілю щодо питань професійної діяльності за умовах реформування охорони здоров'я та обґрунтування на цій основі напрямів та заходів з удосконалення організації дерматовенерологічної служби. 


\section{Список літератури}

1. Improving healthcare quality in Europe Characteristics, effectiveness and implementation of different strategies / R. Busse, N. Klazinga, D. Panteli, W. Quentin. - 2019. - 447 p.

2. European health report 2018. More than numbers - evidence for all. WHO Regional Office for Europe. - Copenhagen, Denmark, 2018. $-164 \mathrm{p}$.

3. Exploring patient participation in reducing health-care-related safety risks. WHO Regional Office for Europe. Copenhagen, Denmark, 2013. -190 p.

4. Frequently asked questions (FAQ). The European Framework for Action on Organizing integrated health care delivery.Copenhagen: WHO Regional Office for Europe; 2016. - 27 p.

5. Global strategy on human resources for health: Workforce 2030 / DRAFT 1.0 submitted to the Executive Board (138th Session) // Health workforce department World Health Organization, Geneva, Switzerland, 2016. - 64 p.

6. Health system considerations: when influenza meets COVID-19 Preparedness and response measures whenCOVID-19, influenza and acute respiratory infectionscoincide in the WHO European Region. Copenhagen: WHO Regional Office for Europe; 2020. - 31 p.

7. Implementing a Health 2020 vision: governance for health in the 21 st century. Making it happen. - Copenhagen: WHO Regional Office for Europe; 2013. - 92 p.

8. Maintaining essential health services: operational guidance for the COVID-19 context. Interim guidance 1 June $2020 .-$ Copenhagen: WHO Regional Office for Europe; 2020. - 61 p.

9. Ellen Nolte and Martin McKee. Caring for people with chronic conditions. A health system perspective. Open University Press McGraw-Hill Education. - 2009. - 290 p.

10. Strengthening and adjusting public health measures throughout the COVID-19 transition phases Policy considerations for the WHO European Region. - Copenhagen: WHO Regional Office for Europe; 2020. - 20 p.

11. Strengthening the health systems response to COVID-19. Adapting primary health care services to more effectively address COVID-19 (17 June 2020). - Copenhagen: WHO Regional Office for Europe; 2020. - 20 p.

12. Strengthening the health system response to covid-19. Preventing and managing the COVID-19 pandemic across long-term care services in the WHO European Region (21 May 2020). - Copenhagen: WHO Regional Office for Europe; 2020. - $32 \mathrm{p}$.

13. Strengthened the health systems save more lives. An insight into WHO's European Health Systems' Strategy. - Access mode : http://www.euro.who.int/__data/assets/pdf_file/0011/78914/healthsys_savelives.pdf.

14. The toolkit for a sustainable health workforce in the WHO European Region / WHO Regional Office for Europe. Copenhagen, 2018. - $82 \mathrm{p}$.

15. Tracking universal health coverage: First global monitoring report/ Geneva: World Health Organization, 2015. - 98 p.

16. Transforming our world: the 2030 Agenda for Sustainable Development. - Access mode : https:// sustainable development.un.org/post2015/transformingourworld.

17. WHO priorities for action towards a Decade of Action on Healthy Ageing(2021-2030), Geneva: WHO, 2017. - 56 p.

\section{References}

1. Busse, R., Klazinga, N., Panteli, D., \& Quentin, W. (2019). Improving healthcare quality in Europe Characteristics, effectiveness and implementation of different strategies.

2. (2018). European health report 2018. More than numbers - evidence for all. WHO Regional Office for Europe. Copenhagen, Denmark.

3. (2013). Exploring patient participation in reducing health-care-related safety risks. WHO Regional Office for Europe. Copenhagen, Denmark.

4. (2016). Frequently asked questions (FAQ). The European Framework for Action on Organizing integrated health care delivery. Copenhagen: WHO Regional Office for Europe.

5. (2016). Global strategy on human resources for health: Workforce 2030 / DRAFT 1.0 submitted to the Executive Board (138th Session). Health workforce department World Health Organization, Geneva, Switzerland.

6. (2020). Health system considerations: when influenza meets COVID-19 Preparedness and response measures whenCOVID-19, influenza and acute respiratory infectionscoincide in the WHO European Region. Copenhagen: WHO Regional Office for Europe.

7. (2013). Implementing a Health 2020 vision: governance for health in the 21st century. Making it happen. Copenhagen: WHO Regional Office for Europe.

8. (2020). Maintaining essential health services: operational guidance for the COVID-19 context. Interim guidance 1 June 2020. Copenhagen: WHO Regional Office for Europe.

9. (2009). Ellen Nolte and Martin McKee. Caring for people with chronic conditions. A health system perspective. Open University Press McGraw-Hill Education.

10. (2020). Strengthening and adjusting public health measures throughout the COVID-19 transition phases Policy considerations for the WHO European Region. Copenhagen: WHO Regional Office for Europe.

11. (2020). Strengthening the health systems response to COVID-19. Adapting primary health care services to more effectively address COVID-19 (17 June 2020). Copenhagen: WHO Regional Office for Europe.

12. (2020). Strengthening the health system response to covid-19. Preventing and managing the COVID-19 pandemic across long-term care services in the WHO European Region (21 May 2020). Copenhagen: WHO Regional Office for Europe. 
13. Strengthened the health systems save more lives. An insight into WHO's European Health Systems' Strategy. Retrieved from: http://www.euro.who.int/__data/assets/pdf_file/0011/78914/healthsys_savelives.pdf.

14. (2018). The toolkit for a sustainable health workforce in the WHO European Region. WHO Regional Office for Europe. Copenhagen.

15. (2015). Tracking universal health coverage: First global monitoring report. Geneva: World Health Organization.

16. Transforming our world: the 2030 Agenda for Sustainable Development. Retrieved from: https://sustainabledevelopment. un.org/post2015/transformingourworld.

17. (2017). WHO priorities for action towards a Decade of Action on Healthy Ageing(2021-2030). Geneva: WHO.

\section{THE TOOLKIT FOR STUDYING THE VIEW OF DERMATOVENEREOLOGICAL SPECIALISTS ON THEIR PROFESSIONAL ACTIVITIES IN THE CONTEXT OF HEALTHCARE REFORM \\ T. S. Gruzieva, V. V. Korolenko \\ O. Bohomolets National Medical University, Kyiv, Ukraine}

Purpose: identification of prospective directions for improving medical care for the population and substantiation of tools for studying the view of dermatovenereological specialists on their professional activities in the context of healthcare reform.

Materials and Methods. The bibliographic, medical-statistical, information-analytical methods are used. The sources used were scientific literature data, strategies and programs of WHO, WHO/Europe, regulating the organization of health services delivery and ensuring their quality; data of the Center for Medical Statistics of the Ministry of Health of Ukraine.

Results. The medical and social research identified modern problems and strategic directions for improving healthcare services for the population in relation to the overall health services coverage, taking into account the challenges and threats, contemporary demographic, epidemiological contexts, etc.

Trends in the incidence and prevalence of diseases of the skin and subcutaneous tissue among the population of Ukraine, changes in the provision of the population with dermatovenerological specialists in the period 20002017 were revealed.

The toolkit has been substantiated for studying the opinions of dermatovenereologists on professional activities in the context of healthcare reform, including demographic, economic, medical, industrial, resource, educational, informational questions, as well as those about the impact of the COVID-19 pandemic on working conditions and the results of the work, about the existing problems and needs.

Conclusions. Conducting a sociological study among dermatovenereological professionals using the proposed tools will contribute to clarify the problematic issues of their professional activities in the context of healthcare reform, vision of development prospects, and will justify the directions and measures to improve the organization of the provision of dermatovenerological care.

KEY WORDS: organization of medical care; dermatovenereological profile; personnel; tools; sociological research; professional development; working conditions; resource provision; COVID-19; reform.

Рукопис надійшов до редакції 27.05.2020 p.

Відомості про авторів:

Грузєва Тетяна Степанівна - доктор медичних наук, професор, завідувач кафедри соціальної медицини та громадського здоров'я Національного медичного університету імені О. О. Богомольця; тел.: +38(050) 382-68-24. Короленко Володимир Васильович - кандидат медичних наук, магістр державного управління у сфері охорони здоров'я, докторант кафедри соціальної медицини та громадського здоров'я Національного медичного університету імені О. О. Богомольця. 